\begin{tabular}{|c|c|}
\hline ANGLES & Angles \\
\hline $\begin{array}{l}\text { NEW PERSPEETIUECE } \\
\text { ANGLOPHONE WORLD }\end{array}$ & New Perspectives on the Anglophone World \\
\hline & $\begin{array}{l}2 \mid 2016 \\
\text { New Approaches to the Body }\end{array}$ \\
\hline
\end{tabular}

\title{
When Bodies Go Digital
}

\section{Claire Larsonneur}

\section{(2) OpenEdition \\ Journals}

\section{Electronic version}

URL: https://journals.openedition.org/angles/1856

DOI: 10.4000/angles.1856

ISSN: 2274-2042

\section{Publisher}

Société des Anglicistes de l'Enseignement Supérieur

\section{Electronic reference}

Claire Larsonneur, "When Bodies Go Digital", Angles [Online], 2 | 2016, Online since 01 April 2016, connection on 07 June 2022. URL: http://journals.openedition.org/angles/1856 ; DOI: https://doi.org/ 10.4000/angles. 1856

This text was automatically generated on 7 June 2022.

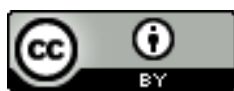

Angles est mise à disposition selon les termes de la Licence Creative Commons Attribution 4.0 International. 


\section{When Bodies Go Digital}

\section{Claire Larsonneur}

Figure 1: Claire Larsonneur, Heading towards the digital

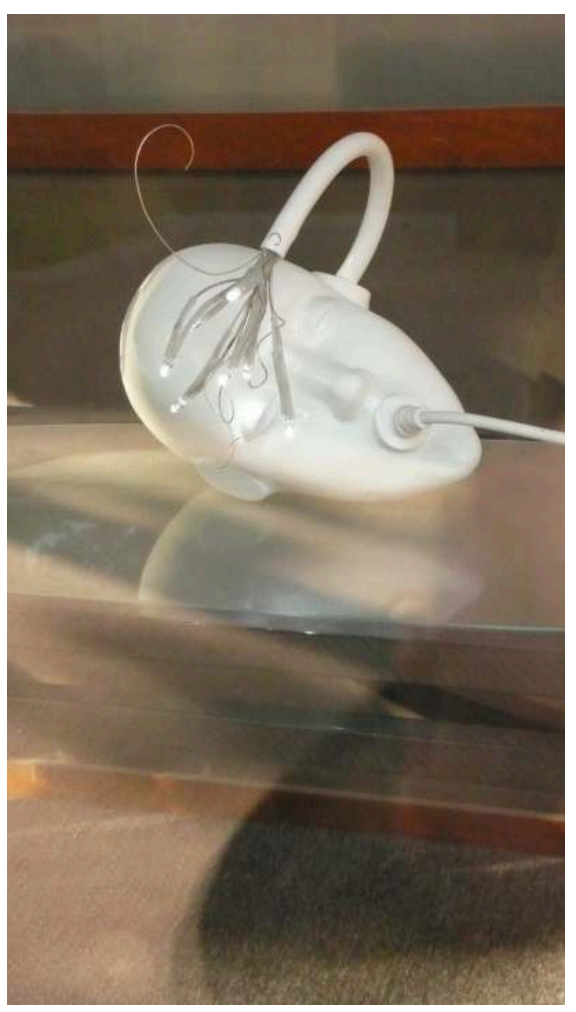

(c) Claire Larsonneur, with permission from the artist.

1 Twenty years ago the adjective 'virtual' was on everyone's lips and widely used to describe the products of new technologies, from videogames to training programmes. What happened beyond the pale of the screen in the depths of computers was labelled 'virtual'. Because these technologies remained opaque for most people, the word took on connotations of mistrust and awe: 'virtual' was the domain of geeks and weirdos, a 
quasi-synonym for fake, illusory, deceptive, unreal. The conceptual divide between real and virtual usually hailed back to Plato's myth of the cave, keeping us on conveniently familiar grounds. Even more reassuring was the implied distinction between what happened within the computer and what happened elsewhere, in 'real life', the screen acting as partition rather than interface. It also neatly matched the distinction between what was material and what was immaterial, understood both in the figurative and the literal sense.

2 The human body became one the most prominent touchstones of this mental divide: it was the ultimate proof of reality, as in "if you pinch and it hurts, then it's real". A spate of novels and films exploited the narrative possibilities of the real/virtual strain, incorporating its ambiguities and paradoxes in their plots: typically EXistenZ and Matrix, both released in 1999, build their suspense on the characters' inability to assess whether their experience was real or virtual.

3 But this changed with the advent of the digital age. Tim Berners-Lee's invention of the World Wide Web in 1989, the launch of Google in 1998, the massive shift towards ecommerce and e-administration over the last ten years, the recent development of connected objects mean that humans are engaging with software in almost every department of life. In other words, digital technologies moved out of the computer and the reassuring divide between real and virtual is becoming obsolete for many. Smartphones and watches, body-tracking apps (counting calories, counting steps, monitoring sleep, displaying selfies) have entered our daily routine. Paradoxically, although these new technologies tend to be considerably more intrusive than virtual reality, only a few of us object to them; most people willingly, even enthusiastically, partake of a digital world tailored to blend in seamlessly with our activities. I would like to explore here a few contemporary works of art and fiction serving as a magnifying glass and a chamber of echoes of our digital condition. Some, like Thomas Pynchon's Bleeding Edge (2013), focus on our very recent past; others, like David Mitchell's Cloud Atlas (2004), Jeanette Winterson's The Stone Gods (2007), Kazuo Ishiguro's Never Let Me Go (2005) or Ari Folman's The Congress (2013), are set in a distant to near future, yet mirror our present.

\section{Perception double and trouble}

4 The most striking and often commented feature of our digital condition is the reframing of our perceptions via digital apparatuses. This started with immersive devices such as virtual reality helmets and extended to the reproduction of entire environments, in 2D or 3D. The following excerpt from Bleeding Edge showcases the disorientating sensory experience of Maxine, a fraud investigator who goes browsing through Web Archer, a fictional equivalent of the Deep Web. The Deep Web, an expression coined by computer scientist Michael Bergman in 2001 (Bergman 2001), describes content that is available on the World Wide Web but has not been indexed by standard search engines. Pynchon's well-researched novel charts the conflation of several momentous events around the turn of this century: the advent of search engines, the attack on the Twin Towers in New York but also the Internet Bubble. ${ }^{1}$ The excerpt nicely encapsulates the dismay, fascination and paranoia Maxine experiences while navigating parallel worlds: 
When the picture returns, she seems to be travelling in a deepspace vehicle... there's a menu for choosing among views, and, switching briefly to an exterior shot, she discovers it's not a single vehicle but more like a convoy [...] Inside Maxine finds corridors of glimmering space-age composite, long as boulevards, soaring interior distances, sculptured shadows [...] Only code, she reminds herself. But who of all these faceless and uncredited could have written it and why? Popping up in mid-air, a paging window appears, requesting her presence on the bridge, with a set of directions. (Pynchon 339)

5 As online navigation smoothly morphs into deep space travelling for the character/ viewer, Pynchon suggests a series of perceptual doubles: Maxine can switch between interior and exterior shots, corridors equal boulevards, closed space mutates into soaring distances. The reframing of basic spatial frames of reference - inside versus outside, small versus big, short versus long, single versus many - produces at first a feeling of disorientation but the character (and the reader in her tow) soon takes it in as perfectly normal, to the extent she needs to remind herself it is a digital representation. Pynchon reactivates here the familiar sci-fi trope of travelling in a spaceship through hypermodern cities, but he subjects his landscape to a number of variations that are consistent with the use of keyboard commands, such as the commands to drag-and-drop an item or extend and minimize a window. Furthermore, the last sentence of the excerpt points at the interactivity of her navigation: the landscape becomes an interface, prompting Maxine to change her route. It appears that the divide between real and virtual ceases to apply since Maxine is actually navigating through the digital environment her screen displays: mid-screen is mid-air in this digital world.

6 This scene, one of the purple patches of the novel, echoes a widespread trend in contemporary arts where the focus is on the sensory experience of the visitor rather than on the work of art as artefact or representation. Museum exhibitions also increasingly use scopic devices such as VR helmets, magnifying glasses, 3D videos. The spectator's sensory experience is therefore mediated in ways that would not be possible without those technological devices. I'd like to refine the notion of 'perceptual doubles' by examining borrowed and enriched perceptions. Borrowed perception usually takes the form of video shots with miniature Go-Pro cameras. The 17-minute video entitled On Air by Laurent Grasso (2009) offers the viewer a literal 'bird's-eye view' by broadcasting the visual experience of a hawk flying over a desert.

7 The increasing availability of portable cameras at affordable prices and the rise of sharing platforms such as YouTube and DailyMotion means borrowed perception is no longer the sole province of artists, Everyone can now create and broadcast them: some attach the camera to the head of an animal (creating endless hours of "kittycam" footage [Golgowski]), others to their helmets when practising extreme sports. The viewer can access the visual sensations of others, sometimes even simultaneously through live feeds. Some reporters have even started to use 360-angle cameras, broadcasting live images that are the exact replica of their experience on the field (Rémy).

8 Enriched perceptions go further and some artists create hiatuses in our perceptions using digital technologies to recalibrate the interaction between the body and its environment. One of the most spectacular works in this genre is the Rain Room (2012) designed by Random, an arts \& design studio co-founded by Florian Ortkrass, Hannes Koch and Stuart Wood. Using custom software, 3D tracking cameras and water 
sprinklers, Random recreated the conditions of a heavy downpour in a room, water falling from the ceiling all over except above the body of the spectator/participant who remains dry. This is made possible because the person's moves are monitored and relayed to the computer, which then shuts down the sprinklers above him/her. Admittedly one must walk rather slowly but the contrast between the rush of water, the surrounding humidity and the experience of one's dry body is intended to be both unsettling and exhilarating.

This media file cannot be displayed. Please refer to the online document http:// journals.openedition.org/angles/1856

As these disorientated, borrowed or enriched perceptions enter our daily lives, we find that our human bodies increasingly operate through a mix of digital and non-digital environments. One may wonder with Eric Sadin if we are not witnessing "the disturbing apparition of a dual regime of sense making which goes beyond the province of computer science or specific industrial applications to question, even to shatter, a number of categories that had hitherto shaped our humanist modernity" (Sadin 2013: 29, my translation)2. Perceptual trouble indeed.

\section{The logic of compositing and immersion}

10 If we go back to Pynchon's description we may notice Maxine does not just look at her surroundings; she picks options from a menu and the result is called a 'space-age composite'. Compositing is one of the new digital techniques that enable video engineers to create a single image by superimposing elements from a scene, for instance the facades of buildings or particular shapes of clouds. Most special effects in films come down to this technique, which requires extensive libraries of data but proves very cost-effective in the long run. What it entails is a wholly different approach to the creative gesture, far from the stroke of the painter's brush or the inspiration of the Muses. Lev Manovich, in The Language of New Media, analyses the organic relation that binds compositing and immersion: "Digital compositing, in which different spaces are combined into a single seamless virtual space, is a good example of the alternative aesthetics of continuity; moreover, compositing in general can be understood as a counterpart to montage aesthetics. Montage aims to create visual, stylistic, semantic and emotional dissonance between different elements. In contrast, compositing aims to blend them into a seamless whole, a single gestalt." (144). And so it seems that the very digital techniques currently in use work towards blurring the divide between the real and the virtual in a way that redefines our relation to representations. The logic of immersion is paramount, focused on erasing all traces of a creative gesture.

11 The Congress, by Ari Folman, precisely tackles this fantasy of seamlessness along with the fragmentation of representation into menu items. Released in 2013, the film recounts the professional itinerary of a middle-age actress (Robin Wright) who is coerced by a Hollywood studio into full digitization of her body and facial expressions (see Figure 2). Once every possible motion of her body has been recorded and stored as data, she is bound by contract never to appear in any film. All subsequent productions featuring her will rely on the digitized footage and compositing techniques. Fiction here is only a step ahead of what is already going on in the entertainment industry, 
where filmmakers have been embedding historical footage into new films for some time and where they can now revive the figure of dead actresses through holograms (Rigoulet).

Figure 2: The actress being digitized, The Congress (2013), directed by Ari Folman, featuring Robin Wright

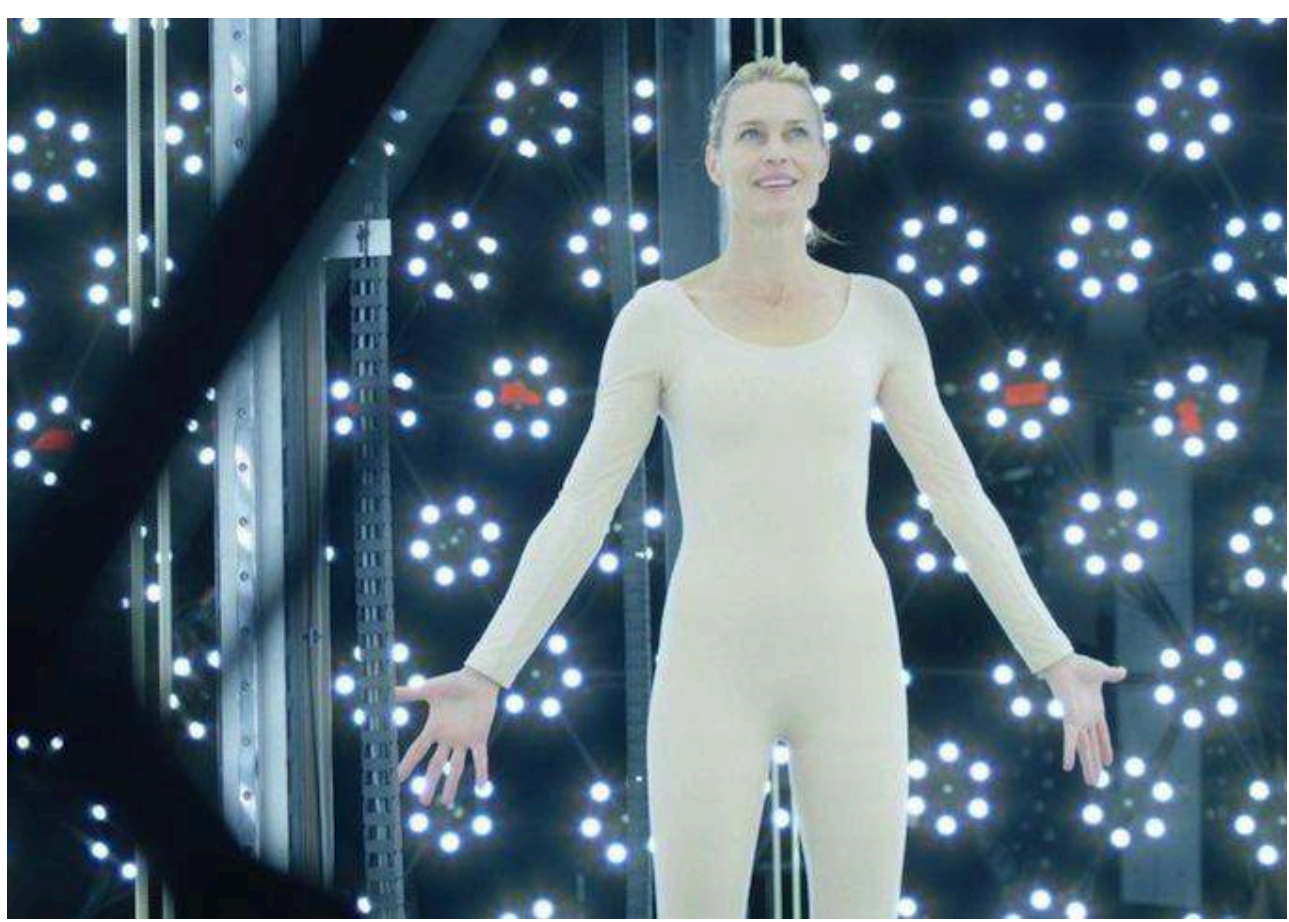

All rights reserved. Source: https://www.imdb.com/title/tt1821641/mediaviewer/rm3616394496

Folman goes further, however, and the film switches, very smoothly and seamlessly, into animation: as Robin drives to a Hollywood party, first the landscape then her reflection in the mirror turn into animated images, followed by her entire self. Not only has the actress been barred from working with her own body, she is made to lose track of her body when she enters the party - an overwhelming, over-reaching dystopia only peopled by avatars. Her struggle to break free from the digitized fantasy then becomes the main focus of the plot.

What makes this dystopia so terrifying is precisely the seamless blending of digital and non-digital features, the fact that digital protocols fuse so smoothly with our daily experience of the world. Folman's animation is very conspicuous, filled with extravagant colours and shapes, and therefore blatantly different from common experience, which alleviates the spectator's feeling of dismay. More unsettling might be the everyday use of Google glasses, which directly superimpose digital information over our visual field. The glasses operate as transparent screens and are meant to be as unobtrusive as possible. Eric Sadin, in "Google Glass : La privatisation de l'attention" (2014), points out the ensuing shift in paradigm: while tablets, phones and watches are carried, wearable technologies, Google glasses (or combat helmets for that matter) are finely tuned into our bodily experience and could be described as sensory protocols ${ }^{3}$. The entertainment industries and everyday gadgets no longer focus on producing digital representations but rather on the design of digital environments where real and digital bodies are superimposed. 


\section{Re-engineering the body} body harvesting. In their sci-fi novels, both Mitchell and Winterson take up an even more disturbing angle: body engineering. The plot of the fifth story in Cloud Atlas confronts humans to clones that have been genetically modified either to fulfil specific tasks or to cater to marketing strategies. For example the waiters of a sordid fast-food outlet have been tailored to draw attention: "The Kyelims were a new attraction: genomed with zoescoped eyes and rabbit teeth, they drew long queues of nikoning fabricant-spotters." (Mitchell 205). Instead of empathy, the feeling they evoke could be described as a mix of fascination and disgust, fabricant clones being featured as figures of abjection. Kyelims are not the only examples of body engineering in the novel, a process that also affects humans, for instance through 'facescaping', i.e. radical plastic surgery, or the use of holograms (Mitchell 334). In The Stone Gods, Winterson goes further and describes a society where everybody has been modified and even 'fixed', which means the process of ageing is stopped at a given time, usually mid-twenties for women, mid-forties for men ${ }^{4}$.

'Every human being in the Central Power has been enhanced, genetically-modified and DNA-screened. Some have been cloned. Most were born outside the womb. A human being now is not what a human being was even a hundred years ago. So what is a human being?'

'You think too much', said Pink. 'I'll get you a drink. It's obvious - cut me and I bleed.'(Winterson 77)

The process bears significant resemblance to the production of chimeras. In Greek mythology the chimera spelt destruction and monstrosity: the compound of lion, snake and goat, found on a number of vases but also cast in bronze as below, was read as a paradoxical mix of nobility (the lion) and baseness (the goat). It offered an improbable and unwieldy composite of body-parts where the tail of the lion morphed into the head of a snake, and thus functioned as a counter-proof of normality. 


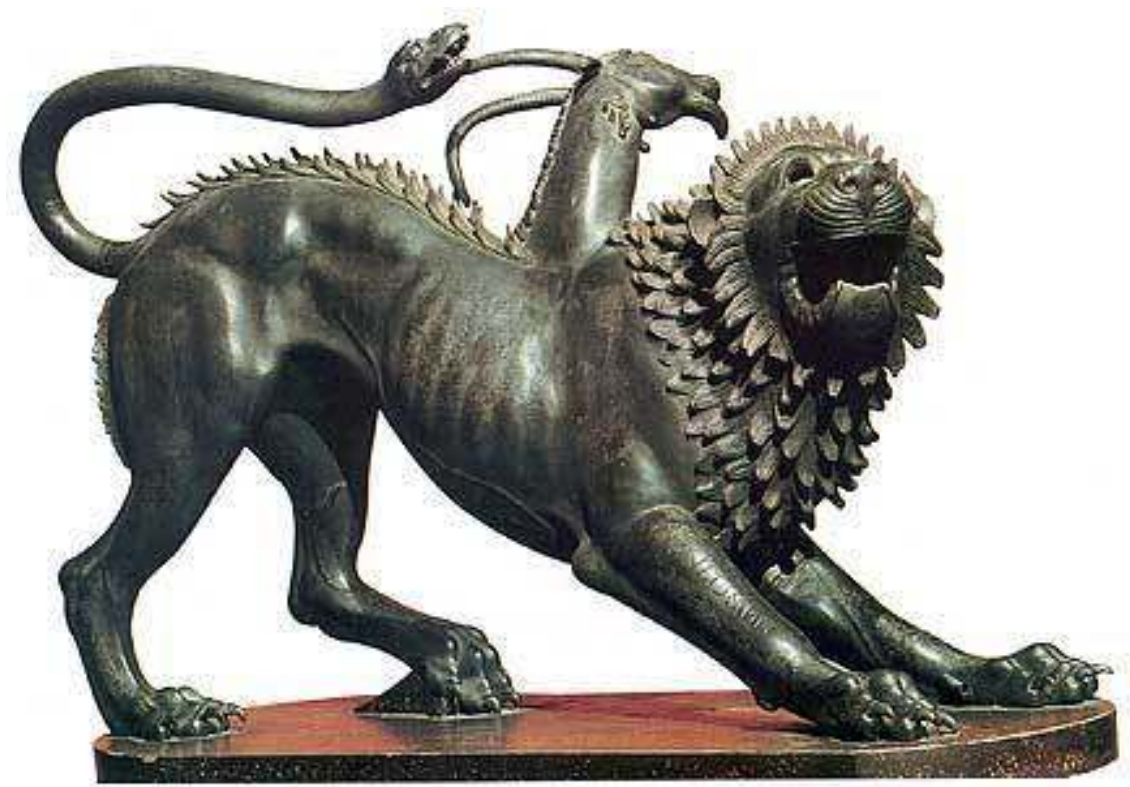

Museo Archeologico Nazionale, Florence. Source: http://firenzecuriosita.blogspot.com/2011/03/lachimera-di-arezzo-si-trova-firenze.html

Today's chimeras by contrast are commonplace: scientists have produced scores of them from glowing rabbits (Rojahn) ${ }^{5}$ to seedless and hairless fruit. Our societies make a lucrative business of creating value through the customization of living creatures, relying again on menu-based libraries of genes. The recurrence of lists in Mitchell's and Winterson's dystopias is a narrative trick that exposes the logic of catalogue that prevails over body-engineering: the reader is given access to a full range of 'products', with technical sheets detailing their characteristics. Similarly, chimeras as not the oneoff exception in our societies: they tend to become everyday commodities. But if we follow that logic, bodies may cease to be the singular instances we are accustomed to, when each person possesses a unique set of physical characteristics. If body parts may be reengineered and sold, then customization and standardisation apply: people may opt for the most popular nose, the eye colour of celebrities, etc. Paradoxically, scientific prowess turns into economic scarcity of choice. For instance, in The Stone Gods, women's clothes are only manufactured in two sizes and chosen by the computer for the client.

'I think you'd look good in numbers one, three and six with matching footwear,' she says from somewhere, nowhere.

She is right, of course, because computers are good at matching things - including people and their clothes. Mind you, we all look more or less alike, and there are only two sizes, Model Thin and Model Thinner, it isn't hard. (Winterson 27)

\section{Continuous body-display and monitoring}

19 Tracking and monitoring are the last steps of this commodification of the body. Indeed surveillance techniques feature prominently in our corpus where tracking devices are grafted onto bodies. In Cloud Atlas, humans wear so-called 'Souls', tiny metallic eggs embedded in the pulp of their fingers; the clones wear collars like African slaves and carry subcutaneous barcodes, like cattle. 
The Soul implanter was ushered in minutes later. A slite, anonymous-looking man, he xmined Hae-Joo's torn finger with professional disdain; tweezed a minute speck from a jelpack; bedded it into fresh tissue and sprayed cutane over the digit. I wondered at how such an insignificant-looking dot confers the rights of consumerdom on its bearers yet condemns those lacking one to an xistence of abject servitude or worse. (Mitchell 334-335)

These devices function as means of identification, like passports, means of geolocalisation and payment like our smartphones and GPS. Tracking devices participate in a global digital panopticon, a theme whose importance in Mitchell's work has been analysed by Rose Harris-Birtill (2015). The same logic applies to outcasts in The Stone Gods, condemned to wear taggers:

You become an X-Cit, an ex-citizen. There will be no record of you ever having existed. You can't travel, you can't buy anything, you can't register for anything, you can't plead your case. You can't use what was your name. When you get out of jail, if you ever get out of jail, you will be micro-tagged for life as an Unknown. You see them sometimes, cleaning the streets, their taggers flashing at fifteen-minute intervals, checked and recorded by the satellite system that watches us more closely than God ever did. (Winterson 30-31)

In fiction as in reality, digital surveillance literally frames the self via auto-censorship and a continuous mirroring of oneself onto digital media. ${ }^{6}$ But tracking is also a social tool, one that enables people to assert their status and promote their performances. One could say that Digital Narcissus is by definition always on stage, as shown by the British mini-series Black Mirror (2011-) named after the description of our screens as black mirrors. Though these works of fiction emphasize the dystopian quality of surveillance by pushing its logic ad absurdum, they may fall short of what is currently happening: in "Students under surveillance", Helen Warrell from The Financial Times (2015) described how recently-released tracking devices for universities can integrate all digital traces left by students (activity logs on educational platforms, involvement in student forums, personal data and spatial localisation) to predict their academic achievement, under the pretext of identifying more fragile individuals to help them.

This last example may trigger a feeling of unease for many. That unease may stem from the new and overwhelming continuum between the logic of media, that of social interaction and that of meaning, which Manovich exposed:

In a post-industrial society, every citizen can construct her own custom lifestyle and "select" her ideology from a large (but not infinite) number of choices. Rather than pushing the same objects/information to a mass audience, marketing now tries to target each individual separately. The logic of new media technology reflects this new social logic. Every visitor to a Website automatically gets her own custom version of the site created on the fly by a database. (42)

Key to this shift is the fact that our daily interactions with digital devices also affect offline living: one could mention the recurrent operations of selecting, sampling, morphing, reframing and compositing, but also the preference for flow (such as continuous upgrade) over feature or the seamless connexion of representation and life, as witnessed in our analysis of bodies. And so in our digital worlds, the main issue is not whether this or that is feasible but rather who is in control. Art and fiction play a dual role here. They experiment with forms and can push these mental constructs to their 
limits, offering us a distorted but plausible mirror. But they can also trigger disquiet and unease, thus running counter to the smooth digital surveillance and steering of our bodies and lives by corporations and governments. Maybe the best account of this dual process lies in Julia Kristeva's analysis of abjection. The digitized bodies of clones, borrowed perceptions and bioengineered chimeras all have in common a form of intimacy with us and yet are not us; hovering between the subject and the object, they could be described as 'abject', unstable entities that threaten order and the sense of self.

It lies there, quite close, but it cannot be assimilated. It beseeches, worries and fascinates desire, which, nevertheless, does not let itself be seduced. [...] It is thus not lack of cleanliness or health that causes abjection but what disturbs identity, system, order. What does respect borders, positions, rules. The in-between, the ambiguous, the composite (Kristeva, 1-4) with the overwhelming desire to reinstate order and control, and the narrator's itch to write it up.

\section{BIBLIOGRAPHY}

Bergman, Michael K. “The Deep-Web: Surfacing Hidden Value”. The Journal of Electronic Publishing 7.1 (August 2001). DOI: 10.3998/3336451.0007.104

Black Mirror. Created by Charlie Brooker. Channel 4, (2011-).

eXistenZ. Dir. David Cronenberg, Alliance Atlantis, 1999.

Golgowski, Nina. "Kittycam reveals domestic cats' secret double-life as America's killing machines”. Daily Mail Online, 8 August 2012. https://www.dailymail.co.uk/news/article-2185622/ Kittycam-collar-camera-reveals-domestic-cats-secret-double-life-Americas-killingmachines.html

Harris-Birtill, Rose. “'A row of screaming Russian dolls': Escaping the Panopticon in Mitchell's Number9dream", SubStance 44.1 (2015): 55-70. DOI: 10.1353/sub.2015.0007

Ishiguro, Kazuo. Never Let Me Go. London: Faber \& Faber, 2005.

Kristeva, Julia. Powers of Horror: An Essay on Abjection. Trans. Leon Roudiez, New York: Columbia UP, 1982.

Manovich, Lev. The Language of New Media. Cambridge, Mass.: MIT Press, 2001. http:// manovich.net/index.php/projects/language-of-new-media

Matrix. Dir. Andy and Lana Wachowski, Warner Bros. 1999.

Mitchell, David. Cloud Atlas. London: Hodder \& Stoughton, 2004.

Pynchon, Thomas. Bleeding Edge. New York: Penguin Press 2013. 
Rémy, Cathy. "Plongée dans l'info". Le Monde, 7 May 2015. [archived: https://web.archive.org/ web/20150522034555/http://www.lemonde.fr/pixels/article/2015/05/07/plongee-dans-linfo_4629755_4408996.html]

Rettberg, Jill. Seeing Ourselves Through Technology. Basingstoke: Palgrave Macmillan, 2014. DOI: 10.1057/9781137476661

Rigoulet, Laurent. “La mort, un business en or à Hollywood”. Télérama. 20 May 2015. https:// www.telerama.fr/cinema/la-mort-un-business-en-or-a-hollywood,126567.php

Rojahn, Susan Young. “Glow-in-the-Dark Rabbits”. MIT Technology Review. 14 August 2013. https://www.technologyreview.com/2013/08/14/15454/glow-in-the-dark-rabbits/

Sadin, Eric. L'Humanité augmentée, Montreuil: Ed L'échappée, 2013.

Sadin, Eric. “Google Glass : La privatisation de l'attention”, Le Monde, 11 novembre 2014. https:// www.lemonde.fr/idees/article/2014/11/12/les-google-glass-preparent-l-accaparement-denotre-attention-par-les-publicitaires_4522156_3232.html

The Congress, dir. Ari Folman, Bridgit Folman Film Gang, 2013.

Warrel, Helen. "Students under surveillance”. Financial Times. 24 July 2015. https://www.ft.com/ content/634624c6-312b-11e5-91ac-a5e17d9b4cff

Winterson, Jeanette. The Stone Gods. London: Penguin, 2007.

\section{NOTES}

1. The Internet Bubble or Dot-com Bubble corresponds to a speculative bubble on information technology start-ups covering roughly 1997-2000. Largely centered on the American market, it burst in 2001.

2. The French quote is: "La formation troublante d'un double régime d'intellection des choses qui ne peut rester cantonné au champ limité de la science informationnelle et à des applications industrielles spécifiques, mais qui bouscule ou pulvérise nombre de catégories qui ont jusque là structuré notre modernité humaniste".

3. "Elles témoignent du franchissement d'un seuil, ne se présentant plus comme des technologies portables, consultables et manipulables de temps à autre, mais comme des protocoles s'adjoignant sans plus de rupture à l'expérience. Elles s'intègrent avec légèreté au visage, exposant, par le biais d'une connexion au réseau, des textes et des images fondus à l'un des deux verres." (Sadin 2014).

4. The plot of the film Time Out (2011) by Andrew Niccols relies on the same fantasy of "fixing" the body at a given age.

5. The subtitle of the article claims "Glowing bunnies are a successful early step in a project aimed at engineering mammals that produce medicines in their milk."

6. See Jill Rettberg's work on self-tracking apps (Rettberg 2014). 


\section{ABSTRACTS}

This article intends to investigate contemporary works of art ("Rain Room", "On Air"), fiction (David Mitchell, Jeannette Winterson, Thomas Pynchon, Kazuo Ishiguro) and films (The Congress, Black Mirror) together with emerging social practices to charter the impact of digital technologies on our relation to the body. Devices such as Google Glasses or Go-Pro cameras prompt a reframing of our perceptions through borrowed and enriched sensory experiences. Digital practices, tailored to blend in seamlessly with our daily activities, contribute to implement further the logic of immersion and compositing described by Lev Manovich in his analysis of new media. Beyond the field of media, digital technologies are also playing a role in the reengineering of the human body itself. Bodies are being produced, tailored and marketed in a society that thrives on continuous body-display and monitoring, raising political and economic issues. Those digital body-chimeras could be described as unstable entities that threaten our sense of order and of ourselves, echoing Kristeva's analysis of abjection.

Comment les technologies numériques affectent-elles notre relation au corps? C'est par l'exploration conjointe de pratiques sociales émergentes et d'un corpus d'œuvres de fiction contemporaines (David Mitchell, Jeannette Winterson, Thomas Pynchon, Kazuo Ishiguro), de films (The Congress, Black Mirror) et d'œuvres d'art ("Rain Room", “On Air") qu'on tentera de répondre à cette question. Les conditions usuelles de la perception sont affectées par des objets tels que les Google glasses ou les caméras Go-Pro, lesquelles génèrent des expériences sensorielles inédites, empruntées ou enrichies. Les dispositifs numériques, conçus afin de s'insérer sans heurts dans notre vie quotidienne, participent du développement de la logique immersive, fondée sur la technique de composition d'images, que décrit Lev Manovich dans son analyse des nouveaux médias. Par delà le champ médiatique, les technologies numériques jouent également un rôle dans l'ingénierie corporelle: au sein d'une société de contrôle qui valorise l'exposition et la surveillance permanente des corps, ceux-ci se voient produits, standardisés et mis sur le marché, ce qui soulève de nombreuses questions politiques et économiques. Les corpschimères numériques ne sont-ils pas des entités instables, susceptibles de mettre en danger la manière dont nous faisons sens du sujet et du monde, relevant de l'abjection telle que la définit Kristeva?

\section{INDEX}

Keywords: digital perception, immersive reality, body engineering, surveillance, abjection, contemporary fiction, digital technology

Mots-clés: perception numérique, réalité immersive, ingénierie corporelle, société du contrôle, abjection, fiction contemporaine, technologie numérique

\section{AUTHOR}

\section{CLAIRE LARSONNEUR}

Claire Larsonneur is an associate professor in translation and British litterature at the University of Paris VIII-Vincennes St Denis. Her research focuses on British hyper contemporary fiction (Mitchell, Swift, McEwan, Winterson, Ballard, Chatwin) and on digital humanities (interfaces and digital tools). Supported by the Arts H2H Labex funding scheme, she has co-managed a cross- 
disciplinary quadriennal research project on the "Digital Subject" (2012-2015) and she is currently organising an international conference on "Posthumanity and digital subjectivities" at the conference centre in Cerisy-La Salle in June 2016. She has published and edited a number of articles and essays on digital humanities, among which Le Sujet digital (co-ed.) Dijon, Presses du réel (2015); La Recherche internet en lettres et langues, Paris, Ophrys (2008); "Revisiting Dejima (Japan): from recollections to fiction in D. Mitchell's The Thousand Autumns of Jacob de Zoet", Substance 44, 136 (2015): 136-148; "Mediations: Science and Translation in The Thousand Autumns of Jacob de Zoet by David Mitchell", in Études britanniques contemporaines 45 (2013) (co-written with Hélène Machinal); and "Put the blame on? A face off between the neuroscientist and the terrorist”, Le Savant fou, Hélène Machinal ed., Presses Universitaires de Rennes (2013): 419-429. Contact: claire.larsonneur [at] univ-paris8.fr 